\title{
Entrepreneurial NPOs in Russia: Rationalizing the Mission
}

\author{
Zhanna Kravchenko $^{1}$ (1) Anastasiya Moskvina ${ }^{2}$
}

Published online: 31 July 2018

(C) The Author(s) 2018

\begin{abstract}
Nonprofit organizations in Russia are introducing for-profit activities as a means of gaining autonomy from external donors, and as instruments of strategic planning and sustainable development. This study focuses on organizations that work with welfare provision and explores how they reconcile entrepreneurial activities with their social mission. More specifically, we interrogate how two institutional logics, business and nonprofit, are defined and reconciled in organizational identities, structures and hierarchies. Socially oriented nonprofits define their mission through service to beneficiaries, through personal and professional dedication to beneficiaries' well-being, and through making an impact on public policies and the society at large. They mimic a business approach in strategic planning and meticulous reporting, but subordinate profit-seeking to social mission by integrating entrepreneurial activities into already existing organizational structures, or by separating them into independent entities.
\end{abstract}

Keywords Social entreprenuership · Institutional logic · Nonprofit welfare provision $\cdot$ Russia

Zhanna Kravchenko

zhanna.kravchenko@sh.se

Anastasiya Moskvina nastya_moskvina@inbox.ru

1 Södertörn Universty, Aldred Nobles Allé 7, 14189 Huddinge, Sweden

2 NGO Development Center, Ligovskiy prospekt 87, 191040 St Petersburg, Russia

\section{Introduction}

Since the collapse of the Soviet Union, one of the key characteristics of nonprofit organizations (NPOs) in Russia has been their dependence on external resources (Jakobson and Sanovich 2010). The emergence of NPOs in the early stages of the liberalization was associated with international donors (Henderson 2002). Gradually, close cooperation with state representatives on national, regional and local levels, as well as fundraising from private donations or business corporations, was also established (Javeline and Lindemann-Komarova 2010; Krasnopolskaya 2012). As a result, nonprofits often find themselves in a precarious situation: they are under the ideological control and economic scrutiny of donor agencies, face competition for often limited funding, and become detached from their social base. This trend is one of the factors contributing to undermining direct democratic participation and true autonomy of civil society vis-à-vis the state and the market (Henderson 2002).

As a result, Russian NPOs are increasingly engaging in profit generation as a means to accumulate resources and strengthen organizational autonomy from external donors. All nonprofits have a legal right to engage in for-profit activities as long as those activities do not contradict statutory goals, and the revenues are used to achieve those goals. Such activities may include provision of fee-based services or commercial goods to broader public, either within the scope of statutory activities or independent from services and goods provided to target groups on nonprofit 
basis. Participation in public contracting ${ }^{1}$ and procurement programs ${ }^{2}$ is another increasingly important mechanism for profit generation, especially for the so-called socially oriented NPOs, SONPOs, ${ }^{3}$ a special category of nonprofits legally recognized in 2010 . These organizations have traditionally engaged in social provision and advocacy (Henderson 2011), but previously never had to do it under market conditions.

Market pressures promote the adoption of "businesslike" approaches in nonprofit sector (Maier et al. 2016) that are in contrast with the norms and practices traditionally associated with SONPOs. Today, SONPOs across the country are offered various forms of capacity-building activities, including off- and online courses, consulting services, and conferences that attempt to bring them into the realm of business practices. Alongside small and medium-size social businesses, they are targeted by state centers for social sphere innovations which, since 2012, have spent 1.5 billion RUB on entrepreneurial social initiatives (Nikolaeva 2017). Because social entrepreneurship still lacks a clear legal definition (Moskovskaya et al. 2017; Moskovskaya and Soboleva 2016), nonprofits often need to identify with or distinguish themselves from the practice of social entrepreneurship (Chuprova 2014), and bear the associated costs and risks. In this article, we attempt to answer following questions: How do Russian SONPOs balance market demands with statutory goals when introducing for-profit activities? What tensions emerge between their nonprofit mission and for-profit activities? What kind of organizational responses do these tensions encourage?

To answer these questions, we examine organizations that established various types of commercial practices in St Petersburg, Russia, and conceptualize strains that these organizations experience. This enables us to demonstrate how SONPOs interrogate their environment and identities. Before doing so, we first give an overview of the development of patterns of resource accumulation for SONPOs in Russia in order to set the research in context. We then explore institutional theory and resource dependence theory to offer a converged account of complex organizational responses to external constraints. The findings demonstrate that tensions between values and practices associated with the nonprofit

\footnotetext{
${ }^{1}$ Federal Law No. 442-FZ "On the basics of social services for citizens of the Russian Federation,” 28 December 2013.

2 Federal Law No. 44-FZ "On contracting system of the federal and municipal procurement of goods, works and services", 5 April 2013.

${ }^{3}$ Federal Law No. 40-FZ "On amendments to specific legal acts of the Russian Federation on support for socially oriented noncommercial organizations," 5 April 2010.
}

institutional logic and consequences of for-profit engagement can be reconciled by rearranging old or creating new structures and processes through blending and compartmentalization that reflect the primacy of nonprofit goals (social impact) over profit goals (revenues). We conclude by discussing what implications our findings have for understanding the development of civil society in Russia in general.

\section{Transformation of Institutional Arrangements and Resource Accumulation in Russian Civil Society}

The transformation of normative foundation and resources for civil society over the recent decades is the starting point for our discussion about the importance of SONPOs' for-profit activities in Russia today. In the context of a nationalized economy during the Soviet period, nonprofit associations provided welfare by channeling state resources into services and benefits (Tarasenko 2015). For instance, trade unions provided housing and childcare and arranged holiday trips and health rehabilitation treatments. Liberalization reforms of the 1990s removed job guarantees, cut provisions, made earlier universal benefits means-tested, and transferred responsibility for social security to local and regional authorities (Cook 2008). In response to the commodification or disappearance of support for the most vulnerable groups of the population, new interest organizations started to form, creating an alternative social safety net for people outside the reach of the state policies (Bindman 2015). Those organizations were membership-based associations as well as nonmembership-based professional NPOs that engaged in both advocacy and service provision, often relying purely on external grants and sponsorships (Kulmala 2011). Transnational donor organizations that were highly influential in setting the nonprofit agenda during the 1990s prioritized human rights organizations and organizations created around specific issues, such as the environment, the AIDS epidemic, gender equality, etc., and largely failed to engage SONPOs that traditionally addressed local social problems (Sundstrom 2005). Private and corporate charity foundations started to gradually emerge during the same period. They mostly support state-run social organizations, such as local orphanages and cultural institutions (Livshin and Weitz 2006), although funding programs for SONPOs have grown over the years.

More than a decade of state indifference toward nonprofits was followed by policies of gradually increasing financial support, as well as scrutiny and control. In 2005, the state introduced grants for nonprofits for the first time and soon after that launched a series of regulations that first 
Table 1 State funding to NPOs, federal programs (thousands rubles), 2016 Source: Ministry of Economic Development 2017

\begin{tabular}{|c|c|c|}
\hline & 2015 & 2016 \\
\hline Subsidies and grants to NPOs ${ }^{\mathrm{a}}$ & $8,114,390$ & $11,326,355$ \\
\hline Grants to resource centers ${ }^{\mathrm{b}}$ & 239,400 & \\
\hline Grants to innovation centers ${ }^{b}$ & 28,000 & \\
\hline \multicolumn{3}{|c|}{ Procurements (across all regions), projects in } \\
\hline Social protection & & 960,635 \\
\hline Education & & $2,081,157$ \\
\hline Health & & 19,487 \\
\hline Sports & & $3,193,759$ \\
\hline Total & $8,381,790$ & $17,581,393$ \\
\hline
\end{tabular}

made it more difficult, ${ }^{4}$ and later almost impossible, ${ }^{5}$ for many of those organizations to rely on funding from foreign donors (Tulaeva et al. 2017). Over the years, local, regional and national funding programs to support nonprofits working with social provision were expanded further. The legal fixation of the category of SONPOs in 2010 can be seen as a consolidation of this trend, incentivizing nonprofits to direct their activities into the sphere of welfare provision. Proclaiming support for SONPOs, the government was redefining and divesting itself of many of its responsibilities in the sphere of welfare provision (Hemment 2009).

Throughout the years, state funding was used to target families with children, young people and the elderly, while organizations working with the most marginalized groups (prisoners, homeless, addicts, etc.) had to rely on other sources, mostly private, corporate or international. Efforts were directed mainly toward informational support, education and cultural activities rather than poverty relief or advocacy (NPO Development Center 2014). Organizations that provided social services were given tax reductions (ASI 2012). Sporadic practices of outsourcing social services started emerging in the mid-2000s (Struyk 2003), but no national policy was formulated until 2015, when the registries of suppliers of social services ${ }^{6}$ were created by

\footnotetext{
${ }^{4}$ Federal Law No. 18-FZ "On amendments to specific legal acts of the Russian Federation," 10 January 2006, introduced limitations as to who can establish a civil society organization, increased the number of reasons why NPOs may be refused registration with the Ministry of Justice and broadened the oversight authority of state agencies.

${ }^{5}$ Federal Law No. 121-FZ "On amendments to specific legal acts of the Russian Federation with regard to regulation of activities of nonprofit organizations performing functions of 'foreign agents,'” 20 June 2012. According to the law, NPOs that receive funding from international donors have to register as "foreign agents" if they also engage in political activities.
}

regional authorities. Organizations enrolled in those registries provide standardized social services for which they are reimbursed by regional governments. SONPOs, however, are not the only actors involved via such contracting schemes. In many regions, for-profit enterprises make up a larger share of providers (Tikhonovich 2015).

The overall scope of financing of nonprofits in general or SONPOs in particular is difficult to estimate due to the complexity of the administrative system and the financing schemes. However, programs run at the national level redistributed funds equal to $1 \%$ of total GDP in 2015, and $2.1 \%$ in 2016 (authors' calculations based on data from the Ministry of Economic Development 2017; OECD 2017; World Bank 2017, see also Table 1 for more details). ${ }^{7}$ Although a detailed analysis of beneficiaries is beyond the scope of this article, it is important to mention that many organizations received state funds repeatedly and from different sources simultaneously, while the selection process was grossly non-transparent (see, for instance, Transparency International's (2014) analysis of management of presidential grants and subsidies from the Ministry of Economic Development). In various funding programs, civil society professionals often act as experts in the process of reviewing applications; however, it was only the management of presidential grants that was delegated to civil society organizations from 2006-2016, before they too became consolidated under control of the newly established Foundation for President's Grants.

\footnotetext{
${ }^{6}$ Federal Law No. 442.

7 This can be to some extent compared to Poland, the country with an "illiberal regime" akin to the one in Russia (Grzebalska and Peto 2017), where in 2011 state funding was directly distributed to NPOs in the amount of less than $1 \%$ of nation's GDP (Departament Ekonomii Społecznej i Solidarnej2012: 32; OECD 2017; World Bank 2017). We are thankful to Elżbieta Korolczuk for help in retrieving this information.
} 
State support to SONPOs generally aimed to generate political legitimacy for the regime (Krasnopolskaya et al. 2015) and opened opportunities for the SONPOs to be involved in policy-making as long as they are not perceived to be in opposition ${ }^{8}$ (Ljubownikow and Crotty 2017). They also need to withstand government audits associated with state financing, which creates additional costs not covered by state grants and contracts. Overall, as Salamon et al. (2015) concluded, the importance of government policy vis-à-vis the third sector has increased during the last decade, but it is realized as a combination of various policies carried out by different agencies, oftentimes in pursuit of very different goals. The current nonprofit regime exhibits elements of both liberal and statist models (Salamon and Anheier 1998): the state retains a major role in regulating and financing social policies, while direct service provision is gradually delegated to nonprofits, partly as a means of constraining their autonomy from the state.

For-profit ventures expand the repertoire of revenuesoliciting practices from relatively passive fundraising into the sphere of production of services and goods, and become increasingly important mechanisms of resource accumulation (Nefedova 2015). As mentioned above, SONPOs developing for-profit activities are sometimes conflated with social enterprises (Moskovskaya et al. 2017) or small businesses (Kings and Kravchenko 2018). However, when it comes to participation in funding schemes for such organizations, they are excluded by virtue of being not business-like enough. For instance, the Economic Development and Innovative Economy program run by the Ministry of Economic Development since 2014 as a way to support small and medium-sized enterprises, defines social enterprises based on the following criteria: (1) they employ of vulnerable groups (people with disabilities, single parents with young children, retirees, people discharged from prison, etc.); and (2) they provide services to people in difficult situations, on condition that these activities bring in at least $70 \%$ of the organization's revenues (Nikolaeva 2017). SONPOs can rarely match these criteria and cannot qualify for this program. What policies and practices will result from debates about social entrepreneurship merits a separate study. For the purposes of this article, it is important to highlight the perceived institutional proximity of commercial activities of SONPOs and social entrepreneurship as organizational forms that implement for-profit operations with the aim to achieve social impact.

\footnotetext{
${ }^{8}$ Nevertheless, even oppositional organizations have been recipients of such grants. For instance, in 2016, the Moscow Helsinki Group, one of the oldest human rights organizations in Russia, received financing for a project on "Promoting development of the system of public control and citizens' participation in public control of state authorities."
}

To summarize, earlier research demonstrated the gradual diversification of patterns of resource accumulation by nonprofit organizations in Russia and the increasing complexity of institutional arrangements of the civil society as a whole during the recent decades. As SONPOs' experiences indicate, one of the patterns of resource accumulation of nonprofit organizations in Russia is intimately related to transformation of institutional framework of welfare provision, specifically, in the sphere of social services. SONPOs are incentivized to engage in public funding/contracting schemes and social business ventures as a means for achieving organizational stability and profitability, with a prospect of a broad societal impact. At the same time, the space for such organizations to engage in contentious collective action has diminished drastically (Flikke 2016). In the following section, we look closer at theoretical perspectives that conceptualize this institutional environment and organizational responses to its challenges and then outline the analytical tools used in this study.

\section{Theoretical Perspectives on Organizational Responses to External Pressures}

Much of theoretical understandings of nonprofit organizational response to political and economic pressures in Russia have been inspired by institutional theory. Earlier studies have reconstructed the history of institution building in civil society and its evolution in light of changing norms, attitudes, resource flows, legal regulations, and the overall political and ideological climate, and have established that NPOs mainly conformed to the norms and practices imposed by various regulatory structures (Jakobson and Sanovich 2010; Ljubownikow and Crotty 2017; Henderson 2002). For instance, during the 1990s, international donor organizations were crucial for the development of infrastructure of civil society, and foreignfunded nonprofits therefore mimicked norms and practices of aid corporations, at the expense of domestic norms of solidarity, cooperation and trust (Henderson 2002). When researchers examine the effects of state funding on nonprofit development, they arrive at a similar picture of NPOs being "sucked" into state bureaucratic hierarchal norms and structures, their associational nature and political activism sidelined (Ljubownikow and Crotty 2017).

While institutional theory recognized the importance of supply and demand of resources for generating dependencies between Russian NPOs and their donors, they emphasized the primacy of the supply and demand of institutional norms for the layout of the nonprofit sector (Jakobson and Sanovich 2010). The overwhelming theoretical conclusion is that Russian nonprofits are too adaptive to their environment (ibid.). They may gain ability to 
transform the life around them when norms and expectations of nonprofits and public authorities align; however, factors that facilitate such alignment are mostly external to organizations (Kulmala et al. 2017). Through mimetic (Henderson 2002) and coercive (Ljubownikow and Crotty 2017) isomorphism, civil society seems to have gradually been deprived of its own institutional constituents.

Notwithstanding the substantial contribution of institutional perspective to understanding the causal impact of environmental constraints on nonprofit organizational behavior in Russia, it has not addressed a possibility of a broader range of organizational responses to such constrains. Empirical evidence of more strategic approaches to normative pressures appeared recently, in studies exploring organizational adaptation to increased state regulation and oppression (e.g. Tulaeva et al. 2017) and indicated a need to improve understanding of how institutional tradition is applied in the Russian context. Analytical tools that identify and explain responses in more detail can be found in a theoretical perspective that synthesizes institutional theory and resource dependence theory (Oliver 1991).

The resource dependence model places a larger emphasis on organizations' ability to have a self-interested awareness and to engage with their environment (Pfeffer and Salanick 1978). Similar to institutional theory, it recognizes the multidimensional character of external pressures and emphasizes that challenges to nonprofit institutional integrity may come from different actors simultaneously when organizational resources are diversified (Meyer et al. 1983). Resource dependence theory, however, places a stronger emphasis on organization's capacity to make active choices when coping with interdepended pressures (Oliver 1991). From this perspective, when Russian NPOs introduce new practices of resource accumulation, such as for-profit activities, they are presented with operational and cultural challenges that are different from those presented by state and foreign donors, but may nevertheless undercut their social mission (Dees 1998), and may be resisted.

Some studies have brought light to the way Russian nonprofits expressed mistrust and even rejection of the ways external resources are made available (Aksartova 2009). However, earlier theoretical conceptualizations of nonprofits' response to external environment in Russia have paid little attention to explore the intrinsic nonprofit rationality. We would like to argue that, in order to understand how organizations engage in financial transactions with different institutional agents, we need to recognize that they "inhabit" their own institutional scripts (Binder 2007), an account of what they are and what they do, what they may strive to preserve while ensuring sustained performance and legitimacy. In fact, institutional theory provides us with analytical tools to carry out analysis of such scripts by offering conceptualization of institutional logics, developed within the framework of understanding isomorphism and hybridity.

The logic of civil society in general or nonprofit sector in particular has not been distinguished in earlier studies, but can be defined as a "set of material practices and symbolic constructions" (Friedman and Alford 1991: 248) that is neither state- nor market-infused. Here, we do not suggest that all nonprofits would adhere to such logic completely, or that other types of organizations cannot adopt the same practices and constructs. We operationalize the nonprofit logic as an ideal type that draws its professional identity from contribution to the social mission, its legitimacy from trust and reciprocity, and its authority from commitment to equality and solidarity (adapted from Skelcher and Smith 2015; Knutsen 2012; Pache and Santos 2013). We further operationalize identity construction as a process of organizational rationalization encompassing integration of formalized roles and rules into a "unified sovereignty" (Hwang and Powell 2009: 272). It has been shown to be one of the key elements in nonprofits' responding to the challenges of the business logic (Maier et al. 2016). It entails construction of relationships with and attitudes toward stakeholders, beneficiaries, funders, volunteers and competitors, and encompasses behaviors related to innovation and risk-taking and development of professional standards. Maintaining norms and relationships requires legitimacy, an expression of organization's trustworthiness and reputation that is often related to funding sources, and authority, a decision-making power rooted in commitment to those norms and relationships (Anheier 2005). Traditionally, studies utilizing the idealtypical approach to understanding hybridity concentrate on how multiple logics coexist (Skelcher and Smith 2015), and how dominant logics elicit isomorphic response (Lounsbury 2007). As isomorphism is not the focus of this study, we only examine how SONPOs experience their nonprofit logic being challenged with respect to identity, authority and legitimacy, and how organizational responses materialize in practice.

Greenwood et al. (2010) have demonstrated that influence of multiple norms can be selective and organizations vary in their receptivity to competing institutional norms. Operationalization of ways in which organizations incorporate normative responses into practice that we use further in the analysis stems from Skelcher and Smith's (2015) theorization of complex organizational forms in the nonprofit sector. In an effort to conform to new norms, organization may assimilate their practices to those norms without necessarily altering the underlying structures, activities or goal formulations; or blend the logics by weaving new norms into existing practices. Such selective conformity can create room for negotiating compromises 
with external stakeholders, but that requires some potential for compatibility between competing logics (Oliver 1991), otherwise the "foreign" logic may overpower the original one (Knutsen 2012). Compartmentalization of competing logics into a specific division within the same organization (segmentation) or into separate but associated organizations (segregation) may facilitate easier resolution of potential pressures (see also Pache and Santos 2013).

To summarize, in our analysis, we follow the converged approach to understanding organizations exposed to various normative settings suggesting that while institutional frameworks shape organizations, organizational response to external influences is not limited to conformity, but may be more complex and strategic. Russian SONPOs engaging in commercial ventures may experience pressure to focus their activities on production-oriented goals, to recognize the need for careful monitoring of output, and to navigate competition with other organizations (Cooney 2006). We argue that understanding of identity, authority and legitimacy as nonprofit is challenged in the process. These challenges are addressed not only at the normative level but are materialized in organizational structures as various forms of assimilation, blending or compartmentalization.

\section{Data and Method}

In order to comprehend how nonprofit logic operates and is being challenged at the level of organizations, we carried out a qualitative ethnographic study in Russia's secondbiggest city, St Petersburg, from autumn 2015 to spring 2017. Although earlier studies argued in favor of expanding research on civil society beyond metropolitan centers, we chose a geographical area with a greater variety of resources available to SONPOs, not least when it comes to development of for-profit activities (Moskovskaya and Mamuta 2008), and where the concentration of resources is not as great as in the capital. Empirical materials were collected through observations and semi-structured interviews.

There is no aggregated data on SONPOs providing forprofit services in St Petersburg, which made it impossible to gather empirical data based on a statistically representative sample of the organizational field. We therefore focused our sampling process on two capacity-building events organized for SONPOs by the NPO Development Centre in St Petersburg: (1) meetings of the Club of Social Entrepreneurs (total $N=10$ meetings, with 25-50 attendees per meeting, ca $30 \mathrm{~h}$ total) and (2) meetings of participants of the support program for social start-ups, "Social Accelerator" $(N=24$ events with 21 participants, ca $173 \mathrm{~h}) .{ }^{9}$ These events became an arena where organizational and individual goals and activities were interrogated and reflected upon, giving us insight into the process of organizational transformation and identity construction. They included individual and group-based training in entrepreneurial leadership, legal framework, product development, planning, management, HR, etc. In an unobtrusive way, we could follow participants' narrations about everyday life in their organizations, organizational and personal professional histories, organizational roles, norms, structures and inter-organizational networks, as well as specificities of their entrepreneurial experiences.

We used observations to structure our sample for subsequent interviews that aimed at helping us get more insight into entrepreneurial experiences and verify tentative conclusions. Following Stinchcombe's (2005: 32) suggestion to focus on "useful distances" between units of analysis in order to capture variation of entrepreneurial practices and organizational forms that were manifested at the observed events, we recruited representatives of SONPOs based on three main manifestations of the role the for-profit activities play in organizational structure: (1) how significant they were as a part of organizations' revenues, (2) at what stage of organizational development they were introduced, and (3) what type of product they created.

As a result, we closely examined twelve organizations: six SONPOs with for-profit activities that generated only a relatively small share of their revenues, two subsidiary forprofit organizations that did not perform nonprofit activities but directed all profits to a SONPO, and four organizations that were established as social enterprises and since then had developed/or were in the process of developing nonprofit subsidiaries and therefore also identified themselves as SONPOs (see Table 2 for more details). These organizations were equally divided by the main type of generated product: educational services (four), social services (four), and consumer goods (four).

All informants occupied executive positions in their organizations as directors (eight) or managers of for-profit divisions/projects (four). Each interview lasted 1-1.5 h, and were carried out immediately after observations at the venue of the club meeting or training session for the Accelerator (two), at the NPO Development Center at a later date (three) or at the informant's place of employment (seven). A limitation of this study is that we did not conduct formal interviews with more than one informant per organization, with the exception of three cases where informants suggested or insisted on inviting along a

\footnotetext{
9 The Club meetings were open to all organizations interested in entrepreneurship in the social sphere. The Accelerator aimed to assist SONPOs and social enterprises in developing specific project ideas and was preceded by a selection process run by the program coordinators based on external evaluations. The first Accelerator ran from October 2015 to June 2016, and the second ran from September to December 2016.
} 
Table 2 Organizations by type of nonprofit and for-profit activities

\begin{tabular}{|c|c|c|}
\hline & Nonprofit activities & Commercial activities/products \\
\hline \multicolumn{3}{|c|}{ For-profit subsidiary to SONPO } \\
\hline FpS1 & Social assistance to cancer patients & Consumer goods, charity shop \\
\hline FpS2 & In-kind assistance to the poor and adults with disabilities & Consumer goods produced only by the target group \\
\hline \multicolumn{3}{|c|}{ Private enterprise with a socially oriented nonprofit division } \\
\hline PeNd1 & Educational and leisure services to families with young children ${ }^{a}$ & \\
\hline $\mathrm{PeNd} 2$ & Educational services to children with development problems ${ }^{\mathrm{a}}$ & \\
\hline PeNd3 & Social assistance to the disabled ${ }^{\mathrm{a}}$ & \\
\hline PeNd4 & $\begin{array}{l}\text { Social assistance to young adults leaving state foster care } \\
\text { institutions }\end{array}$ & $\begin{array}{l}\text { Corporate social responsibility programs to local business } \\
\text { enterprises }\end{array}$ \\
\hline \multicolumn{3}{|l|}{ Nonprofits } \\
\hline SONPO1 & Social assistance to adults with disabilities & Educational services for the general public \\
\hline SONPO2 & Educational services to young adults with disabilities & Consumer goods \\
\hline SONPO3 & Social assistance to marginalized groups & Consumer goods \\
\hline SONPO4 & Social assistance to children with a rare genetic disease ${ }^{\mathrm{b}}$ & \\
\hline SONPO5 & Environmental activism and education ${ }^{\mathrm{b}}$ & \\
\hline SONPO6 & Social assistance to families with disabled young adults ${ }^{\mathrm{b}}$ & \\
\hline
\end{tabular}

colleague whose expertise differed from their own. Secondary materials, such as annual reports, websites, promotional materials, were not collected systematically and therefore were used as background information.

Data collection, reduction and analysis were conducted concurrently. Field-notes were taken by hand in Russian during the observed events. Interviews were subsequently transcribed in Russian. All identifiable information about the interviewees and organizations was de-identified in all materials. After obtaining the sense of the whole through reading transcripts and field-notes several times, the open coding (in Russian) was launched manually, focusing on manifest content (Elo and Kyngäs 2008) as a means of both further immersing in and reducing the data (Forman and Damschroder 2008). It was only the first author who conducted the coding to avoid the challenge of ensuring intercoder reliability (Elo et al. 2014); the task of the second author was to review the results, compare them across the data, and assess the quality of categorization. The coding did not generate data that can be compared meaningfully using statistical tests; instead, we arranged the patterns of categories thematically and use quotations to illustrate these patterns.

We applied directed content analysis (Hsieh and Shannon 2005), using concepts introduced in the previous section as coding categories, and matching the initial open codes to the predetermined ones. We thus focused on organizational identity, legitimacy and authority in narrations about consequences of introducing for-profit activities at a nonprofit, and organizational responses indicating conformity or non-conformity, and responses that could specifically be identified as assimilation, blending or compartmentalization. We begin the next section by examining the manifestation of the nonprofit logic and then present how introduction of business practices interrogates the nonprofit logic and practice.

\section{Nonprofit Institutional Logic, Tensions and Organizational Arrangements}

\section{The Social Mission}

When formulating roles, goals and means by which to achieve them, SONPOs create their nonprofit identity along three lines: assistance to excluded groups of population, professional standards and societal impact. At the core of their identification, as part of the nonprofit sector is ability to provide social support to people who otherwise would be excluded from what is perceived as normal social practice, and to facilitate access to social statuses and geographical spaces they otherwise would not reach. The character of work varies substantially, from organizations that gradually grow from self-help groups to projects that channel charitable work of large business corporations. Such SONPOs define their work as a complement (Najam 2000) or an 
alternative to a failing social welfare system, because they address social issues that state authorities (local, regional or national) overlook due to lack of competence, or are unable to manage due to curtailment of public social commitments.

Whether organizations use public funds or rely on revenues from for-profit activities, they formulate their strategies and evaluate their results based on how they can secure particularistic interests of target groups as social rights, even though nonprofits usually cannot provide universal guarantees for those rights (Marwell and Calabrese 2015). For instance, head of the for-profit division of an organization that provides medical and rehabilitation care to children with a rare genetic disorder (SONPO4) emphasized that one of their main achievements is getting acknowledgment of the disease by the Ministry of Health, and making the affected families visible in the current diagnostic practice. Similarly, the lack of state services to children with development problems and inability of many families to afford market prices for education and rehabilitation services, has driven a small but successful social enterprise to expand into nonprofit activities:

"Look, there is only one school and one daycare center for children with autism in the city. Children are often not ready to transfer to general educational institutions [that provide no specialized assistance] when the law requires them to!... State institutions are being closed. Soon everything will be provided on a commercial basis. But someone has to do it [for the poor]." (PeNd2)

Both the urgent needs of the socially vulnerable groups and the long-term extensive consequences for them and the society at large are imprinted in the organizational rationale that allows them to identify with the nonprofit sector. Such claims are more difficult to make for organizations that have broader target groups, such as environmental SONPOs. They frame their efforts as aiming to shape common-pool resources and provide public goods not secured as citizenship-based social rights (Ostrom 1990). For instance, an organization working with waste collection, SONPO5, finds it much easier to engage people in cleaning public parks than residential areas, because the parks are excluded from local community services and can only be cleaned with volunteer efforts.

Here, identification of organizational identity based on nonprofits' relation to stakeholders and beneficiaries (Hwang and Powell 2009) is also connected to their ability to attain authority and legitimacy. While most of the organization work with issues which their employees do not experience personally, authority to make professional decisions is drawn from the commitment to address grave social injustices as well as from striving for self-realization.
The former permeates all work with marginalized groups of population that fall outside of the public welfare system, as in the above quotation. The latter is articulated when organizations have to address a broader public. For example, employees of the environmental organization (SONPO5) that, unlike other SONPOs in the sample is not directly involved in social provision, expressed that their ability to command resources and advocate for their cause, is based on self-identification as civic activists: "It just happens to be a niche where we find self-fulfilment."

None of these organizations are membership-based and therefore do not derive trust inside organization (Skelcher and Smith 2015). Instead, they draw their legitimacy by extending the principle of reciprocity and "democratization of resource allocation" (Knapp et al. 1990: 209) to beneficiaries, or even to those who contribute donations, do paid or volunteer work in the organization. For example, one of the organizations in the sample built their business model on the notion of charitable work as a form of consumption. SONPO6 offers care to families with severely disabled young adults by engaging other families as caregivers, and identifies both the client and the service provider as beneficiaries of the organization. Although the "helpers" receive symbolic wages they also benefit from "deep communication and engagement" with the "helped" family.

Organizations rationalize their professional standards of conduct based on a commonly shared assumption that special needs of beneficiaries require a professional approach, even though broad social solidarity is a foundation for recognizing their social rights. They often rely on volunteers for fundraising, while administrative tasks or direct contact with beneficiaries are left to specialists trained in service provision. Despite a high degree of standardization and reliance of formalized roles, usually associated with professionalization of the third sector (Hwang and Powell 2009), professional legitimacy of paid and unpaid workers derives from their contributions to addressing the social problem. For instance, a head of the for-profit division of SONPO4 suggests that the professionalized organizational process is not an aim in itself but a precondition for systemic change:

"When you see these wonderful children, you realize you need to change something so that when they grow up they are fine. I am a trained psychologist and started in the third sector in this capacity; over the years, I tried out different positions, and I found out that I am better at organizing work and I found it was more interesting to me. A clear structure helps you [achieve social change]."

Nonprofits often lose the competition for qualified employees to for-profits, and therefore professionals' 
commitment to these organizations may be temporary. However, the quality of the professional contribution is expected to strengthen the mission despite its potential short duration.

Commitment to social issues and self-realization, an individual-oriented approach, strong personal dedication and an ambition to transform the society at large permeate organizations' nonprofit identities. When entrepreneurial practices are introduced, some of these institutional elements become contested.

\section{Profits Versus the Mission}

As the core of nonprofit identity is linked to assistance to socially excluded group, there is as strong expectation that services should be provided by the SONPOs free of charge. One of the ways to reconcile this expectation with the realities of profit seeking is to target those who are not part of the statutory beneficiary groups with the same services and products. Justification for commodification of some activities is often based on the fact that it yields financial and social returns on investment that make nonprofit efforts more effective and sustainable (Meyer and Simsa 2014). One of the organizations in our sample, for instance, sells to large business corporations volunteer programs that benefit graduates of state foster care institutions for children with learning difficulties (PeNd4). Business organizations pay to be able to provide short-term internships and to help young adults to adjust to independent living. Profits from sales are used to support other types of support for the same target group. SONPOs' beneficiaries can also be expected to pay for services they receive, but only if those services are expected to be a matter of particularistic need rather than a general societal failure. When an organization finds itself operating in the realm where state intervention is expected or even preferred, for instance, in the area of medical rehabilitation and treatment, SONPO 4, a different rationale may prevail. Project manager attending the Social Accelerator explained that one of the main challenges in developing a for-profit service for families with children with a rare genetic disease was that the organization itself was reluctant to receive payment, even when they find their own beneficiary group might be inclined to pay.

International research has argued that profit-driven activities compromise SONPOs' legitimacy in the eyes of the groups and communities they represent, and more importantly, prevent them from acting on behalf of the public good (Eikenberry 2009). When services are commercialized, the claim that organization facilitates reciprocal exchange can no longer be made. Therefore, SONPOs are more ready to charge for work that aims to improve individuals' quality of life but is not considered to be essential for their well-being, as for instance, did SONPO6 that provides temporary care while parents of disabled children run errands or simply have a chance to rest. They do it by evoking lingering paternalism associated with the Soviet welfare system (Cook 2008), as in the quotation below, where a project coordinator asserts that their beneficiaries can afford to buy services but do so only when they do not consider those services to be part of their social rights:

"Before, everything was for free; it was good, everyone got everything. [Today] all services are being commercialized and people are not ready for that. That is, financially they are ready, [disability] pensions are often good enough. But there is a psychological discomfort; 'Why should I pay [when I have a right to it]?"”

While the nonprofit logic dictates that organizations compensate when public social provision fails to provide for poor and marginalized groups, for-profit activities require redefining those groups as market consumers.

At the same time, professional expertise, which from the nonprofit perspective is evaluated based on one's contribution to the well-being of beneficiaries, turns away from social problems and toward internal organizational processes. Personal dedication gets in the way of organizational stability and growth because it prescribes selflessness. From the for-profit perspective, professionalism implies that the individual approach needs to be traded for an approach that focuses more on organizational goals (Hwang and Powell 2009). For instance, the abovementioned organization working with young adults leaving state foster care system (PeNd4) transformed a traditionally individual-based nonprofit practice into a recruiting-like agency in the following way:

"I worked in (nonprofit) recruitment [for the disabled] earlier and we had an individual approach, based on clients' needs. Now we start with the needs of the company [that has a vacant position]. We pool out several candidates, and whatever person is chosen, it is a success for us. If you start with the needs of a specific person, you try once and fail, you try again and fail... Filling the vacancy is more important to us."

Professionalization maintains that innovating social impact is achieved not (only) by means of personal and direct involvement with the beneficiary group, but by organizations being responsible for the well-being of their employees, maintaining their reputation in the eyes of stakeholders and developing standardized procedures of operation. Instead of risk-taking and competitive positioning, often associated with the business rationality (Alexander and Weiner 1998), SONPOs instrumentalize 
this rationality in strategic planning and meticulous reporting. Many informants indicated that dedication to the mission will not bring substantial effects if the work is not conducted in a business-like manner, that is, without strategic and detailed planning, accounting and thorough paperwork. As one of the organizations discovered, despite the fact that for-profit activities are not likely to become their primary or even significant source of funding, learning from their business mentors lead them to rearrange some fundamental internal processes: "We have reorganized our website, reconsidered expenses and products... Now we aim to organize our training programs so that everything they produce could potentially be retailed" (SONPO1). In contrast to private enterprises, SONPOs are not ready to comply when for-profit activities incentivize to subordinate creative efforts and emotional attachments to long-term financial stability. The same nonprofit leader expressed it as follows:

"If we establish an enterprise, say, a bakery, a business goal will be to sell bread. But if our aim is to give a set of skills to a group of disabled guys [by hiring them at the bakery], as a nonprofit we will focus on making the process of baking simple, clear, safe and interesting for them. We will spend our resources on that, not on selling the bread."

Partaking in state-run procurement programs, although potentially burdensome and unreliable (Knapp et al. 1990), is conceived of as an acceptable way to retain authority that is potentially threatened by curtailment of emotional commitment. It allows commercializing services without having the beneficiary groups pay, and without having to enter actual market relations and develop products, marketing strategies and sales instruments, even though SONPOs are forced to compete with small- and mediumsized business enterprises. SONPO5 that builds their profitseeking on state procurement programs rationalizes the prospective challenges of dealing with the state bureaucracy as a part of growing into a reputable organization, expanding the scope of stakeholders, and reaching out to a broader society:

"It is important to us that the state understands that [our work] is important, to be sought-after. When we register [as a social service provider for state procurement programs], the paperwork will change, some of the individual approach will move to the background [because services will be standardized]. But we will be able to fund from other sources cases that are beyond the scope [of state funding]."

Although nonprofits are wary of the unpredictable legislative process, the brutality of the bureaucratic machine and the lack of trust in the long-term stability of state programs, they consider procurements as a way to influence policy. Building relationships with policy-makers, many strive to influence which services are included in state programs and how delivery standards are defined, thus acting not only as a complement or an alternative to, but a driving force for the failing public welfare system (Kulmala et al. 2017, cf. Badelt 1997).

\section{Organizational solutions}

While organizations in our sample vary with regard to internal hierarchies, professional compositions and interorganizational ecologies, the common denominator for their approach is not a clear assimilation, i.e., change in norms without change in practices, but blending or compartmentalizing nonprofit practices (Skelcher and Smith 2015). With both approaches, the organizations attempt to coordinate profit-seeking while balancing, pacifying and bargaining with various stakeholders (Oliver 1991).

Blending commercial activities into ordinary operation occurs when SONPOs provide services to the beneficiary groups: care and rehabilitation, housing and food, education and recreation. Nonprofits that have more horizontal decision-making processes or rely upon volunteers may staff their commercial activities with members that have individual preferences and interests in entrepreneurship, building on social networks and expertise outside of the organization. In larger or more hierarchal organizations, for-profit practices are more clearly separated, compartmentalized, and fall under the jurisdiction of executive directors that have to ensure that the social mission remains the organizational priority.

Blending strategies often mean that an SONPO has separate book keeping for nonprofit and for-profit target groups, but the organizational structure and activities are the same (e.g. PeNd1-3, SONPO4-6). As the same services are provided on the nonprofit and for-profit basis, clients may become charity beneficiaries because of ad hoc decisions made by managers rather than because of systematic targeting work. When not grounded in professionalism, such flexibility may lead to inconsistency and lack of accountability (Knapp et al. 1990). Also, commercial activities in these organizations often constitute only a small share of revenues and are treated as means of creating awareness and motivation through commercial consumption. As one of our respondents asserted: "You do not value what you get for free!" (SONPO5).

Compartmentalization of commercial activities is easier to accomplish when organizations develop manufacturing of souvenirs (SONPO3), art or clothing (FpS2, SONPO2), or create virtual and physical commercial spaces where such commodities can be retailed (FpS1). Sometimes, the separation does not lead to the legal creation of a subsidiary 
organization, but rather an autonomous subdivision (SONPO2, 3, 6). When commercial activities are introduced in the form of a subsidiary organization, their strong connection to the parent organization at the early stages of development provides access to already existing resources and expertise. As subsidiary organizations become able to sustain themselves, they may not need to diversify their resources via the parent organization. They gain more practical autonomy together with a more critical perspective on how SONPOs work. The more for-profit entities are spatially and operationally removed from the parent organization, the more clearly they vocalize that the nonprofit approach lacks strategic planning and clear goal setting. For "blended" organizations, similar sentiments are part of self-criticism; for separated subsidiaries, it signifies their "otherness" from the "traditional" nonprofit approach, even when they emphasize that they are "just like everybody else in the sector" (FpS1).

At the same time, despite embracing the market norms of standardization, formalization, output-oriented planning and monitoring, subsidiary organizations are able to subjugate their practices to the logic of the parent organization without experiencing any dissonance. As the director of a charity shop (FpS1) explains, this eliminates the possibility of tension between different parts of the holding:

"There cannot be contradictions [between the parent organization and the subsidiary] because there is only one goal. Let's say I have 200,000 rubles. I can reinvest it into new products, renovation, bonuses to employees. But the foundation tells me they want this money. They will get it without a doubt. Everyone knows it, it has happened repeatedly. I will sacrifice our profits if [the foundation] needs it."

Legal separation and subordination lock market-oriented pressures with the subsidiary entity, allowing the SONPO to avoid conflict between the logics (Oliver 1991). Subsidiary entities in such holdings may engage in fundraising for the parent organization, but not for their own needs, and when doing so they even may define the value of their products as instruments of outreach rather than of consumption per se.

What draws the attention of the general public to commodities produced by such organizations is that, unlike their "blended" counterparts, they may actively involve their beneficiaries in the process of production. For instance, FpS2 employed adults with disabilities in footwear manufacturing and $\mathrm{FpS} 1$ created charity shop to retail precisely this type of goods. On the other hand, SONPO2 used art produced by the target group for merchandize without paying wages to the artists, and the lack of organizational capacity to become an employer to their target group was one of the main reasons why SONPO1 did not monetize their clients' art, and developed other type of forprofit services to the broader public. Whereas service providers always at least consider taking part in state procurement competitions, autonomous subsidiaries never specifically target public authorities as consumers of their products, although they participate in state programs supporting small or medium-sized businesses. Such programs provide subsidies, partial compensation or interest-free credits to support operations and production or to pay rents.

\section{Conclusion}

Like many nonprofits in other countries, Russian SONPOs are propelled into engagement with the market by competition for external resources emerging from within the third sector (Young and Salamon 2002; Richter 2008). The aim of this article was to explore responses by Russian SONPOs to pressures that emerge when they develop forprofit ventures as means of generating resources. In our sample, we observed that despite differences in organizational forms and types of work, these organizations share dedication to beneficiaries, and to the principles of reciprocity, equality and solidarity as core elements of nonprofit institutional logic. Introduction of for-profit activities challenges all of these elements: beneficiaries may need to be reimagined as consumers and much broader social groups need to be targeted by commercial products and services; organizational goals may shift from providing access to imperative social rights toward providing services and products that are not essential or at all related to the beneficiary group; goals may become less beneficiarycentered and more oriented toward maintaining stable financial flow. When addressing these challenges organizations are selective and strategic in how they adopt, combine or separate different institutional scripts, ensuring their compatibility within organization (Oliver 1991).

Seeking to go beyond the established view of conformity as the prevalent response of Russian NPOs to institutional pressures, we demonstrate the resilience of their commitment to social mission, even when it contradicts external pressures. Both blending and compartmentalization strategies allow integrating some business-like practices while subverting instruments of profit generation into tools of outreach, fundraising or redistribution. This finding grants nonprofits more agency than earlier studies suggested, and may be relevant for understanding how they navigate other pressures that may aim to tame or undermine the civic impetus in their activities. The increasing pressure for business-like practices from the authorities can be seen as a part of state "colonization" of civil society (Hodgson 2004), an attempt to decrease the space for and increase the costs of giving expression to social 
values, strengthening collective identity, and empowering collective action (Eikenberry and Drapal Kluver 2004; Mercer 2002). Even though the current governance regime offers little space for nonprofits to influence their environment (Stewart and Dollbaum 2017), it is all the more important to reveal that they may find strategies to strengthen autonomy and organizational capacity. In their commercial pursuits, SONPOs mobilize non-material resources such as social capital and trust, voluntarism and philanthropy, raise public consciousness regarding social inequality and exclusion, and help establish claims to state protection where it previously did not exist (cf. Salamon 1987).

Our conclusions need to be seen in light of several limitations. Because cases for the analysis were sampled from participants of capacity-building events for SONPOs in the process of developing for-profit activities, we were not able to access well-established social enterprises and cannot contribute to the debate about differences and similarities between these types of organizations (Moskovskaya et al. 2017; Moskovskaya and Soboleva 2016). Earlier research on hybridity demonstrated that business logic eventually prevails when it contests the nonprofit logic, although they intertwine to create a continuous spectrum of values and activities rather than a binary opposition (Zhang and Swanson 2013). Since the sample included nonprofits with incipient for-profit activities, we cannot reject the possibility of higher isomorphism than was observed in the study. It is impossible to estimate the prevalence of the patterns we identified due to the small size of the sample and the qualitative character of the study. These limitations notwithstanding, this study brings attention to the fact that while macroeconomic and political pressures have strong isomorphic power, Russian SONPOs may develop different operational structures and rationalities in an effort to strategically respond to those pressures. It also suggests potential variation in interpretations of exogenous permutations and the importance of internal processes and structures that are dynamic and not necessarily deterministic (Horvath et al. 2018) and gives rise to questions about consequences of adopting specific responses and factors determining these responses.

Acknowledgements The authors would like to thank two anonymous reviewers for their insightful comments and recommendations. We are also grateful to Noomi Weinryb, Södertörn University, for her invaluable support throughout all stages of our work on this article.

Funding Zhanna Kravchenko's work was supported by the Swedish National Research Council, Grant 2014-1557. Anastasiya Moskvina has not been compensated for her research work. She received wages from NGO Development Center for her work as Project coordinator, and took part in this study in her free time. Her employer was informed about her participation in the research Project.

\section{Compliance with Ethical Standards}

Conflict of interest The authors declare that they have no conflict of interest.

Ethical approval All procedures performed in studies involving human participants were in accordance with the ethical standards of the Swedish National Research Council and with the 1964 Helsinki declaration and its later amendments or comparable ethical standards.

Open Access This article is distributed under the terms of the Creative Commons Attribution 4.0 International License (http://crea tivecommons.org/licenses/by/4.0/), which permits unrestricted use, distribution, and reproduction in any medium, provided you give appropriate credit to the original author(s) and the source, provide a link to the Creative Commons license, and indicate if changes were made.

\section{References}

Aksartova, S. (2009). Promoting civil society or diffusing NGOs? D., Hammack, \& S. Heydemann (Eds.) Globalization, Philanthropy and Civil Society. Projecting Institutional Logics Abroad (pp. 160-191). Bloomington: Indiana University Press.

Alexander, J. A., \& Weiner, B. J. (1998). The adoption of the corporate governance model by nonprofit organizations. Nonprofit Management and Leadership, 8(3), 223-242.

Anheier, H. (2005). Nonprofit organizations: Theory, management, policy. London: Routledge.

ASI. (2012). 100 voprosov pro NKO. Chto nuzhno znat', chtoby vasha deiatel'nost' byla uspeshnoi. (100 question about NGOs. What you need to know in order to have a successful practice). Moskva: Agenstvo sotsial'noi informatsii.

Badelt, C. (1997). Entrepreneurship theories of the non-profit sector. VOLUNTAS: International Journal of Voluntary and Nonprofit Organizations, 8(2), 161-178.

Binder, A. (2007). For love and money: Organizations' creative response to multiple environmental logics. Theory and Society, $36(6), 547-571$.

Bindman, E. (2015). The state, civil society and social rights in contemporary Russia. East European Politics, 31(3), 342-360.

Chuprova, K. (Ed.) (2014). Predprinimatel'skaia deiatel'nost NKO. (Commercial activity of NPOs). St Petersburg: NGO Development Center. Online, https://ngokitchen.ru/wp-content/uploads/ 2015/12/Predprinimatelstvo-NKO.pdf. Accessed January 29, 2018.

Cook, L. J. (2008). Postcommunist Welfare States: Reform politics in Russia and Eastern Europe. Ithaca: Cornell University Press.

Cooney, K. (2006). The institutional and technical structuring of nonprofit ventures: Case study of a U.S. hybrid organization caught between two fields. VOLUNTAS: International Journal of Voluntary and Nonprofit Organizations, 17(2), 143-161.

Dees, G. (1998). Enterprising nonprofits. Harvard Business Review, $76(1), 54-67$.

Departament Ekonomii Społecznej i Solidarnej (2012). Program Fundusz Inicjatyw Obywatelskich na lata 2014-2020. Online, http://www.ekonomiaspoleczna.gov.pl/Program,FIO,20142020,1189.html. Accessed 24 January 2018.

Eikenberry, A. M. (2009). Refusing the market: A democratic discourse for voluntary and nonprofit organizations. Nonprofit and Voluntary Sector Quarterly, 38(4), 582-596.

Eikenberry, A. M., \& Drapal Kluver, J. (2004). The marketization of the nonprofit sector: Civil society as risk? Public Administration Review, 64(2), 132-140. 
Elo, S., Kääriänen, M., Kanste, O., Pölkki, T., Utrianen, K., \& Kyngäs, H. (2014). Qualitative context analysis: A focus on trustworthiness. Sage Open, 4(1), 1-14.

Elo, S., \& Kyngäs, H. (2008). The qualitative content analysis. Journal of Advanced Nursing, 62(1), 107-115.

Flikke, G. (2016). Resurgent authoritarianism: the case of Russia's new NGO legislation. Post-Soviet Affairs, 32(2), 103-131.

Forman, J., \& Damschroder, L. (2008). Qualitative content analysis. In L. Jacoby \& L. Siminoff (Eds.) Empirical methods for bioethics: A primer. Advances in bioethics, V. 11 (pp. 39-62). Emerald Group Publishing Limited.

Friedland, R., \& Alford, R. R. (1991). Bringing society back in: Symbols, practices, and institutional contradictions. In W. W. Powell \& P. J. DiMaggio (Eds.), The new Institutionalism (pp. 232-263). Chicago, IL: University of Chicago Press.

Greenwood, R., Diaz, A. M., Xiao Li, S., \& Lorente, J. C. (2010). The multiplicity of institutional logics and the homogeneity of organizational responses. Organizational Science, 21(2), $521-539$.

Grzebalska, W., \& Peto, A. (2017). The gendered modus operandi of the illiberal transformation in Hungary and Poland. Women's Studies International Forum. https://doi.org/10.1016/j.wsif.2017. 12.001 .

Hemment, J. (2009). Soviet-style neoliberalism? Nashi, youth voluntarism, and the restructuring of social welfare in Russia. Problems of Post-Communism, 56(6), 36-50.

Henderson, S. (2002). Selling civil society: Western aid and the nongovernmental organization sector in Russia. Comparative Political Studies, 35(2), 139-167.

Henderson, S. (2011). Civil society in Russia: State society relations in the post-Yeltsin era. National Council for Eurasian and East European Research. Online, https://www.ucis.pitt.edu/nceeer/ 2011_824-17_Henderson.pdf. Accessed 07 September 2016.

Hodgson, L. (2004). Manufactured civil society: Counting the cost. Critical Social Policy, 24(2), 139-164.

Horvath, A., Brandtner, C., \& Powell, W. W. (2018). Serve or conserve: Mission, strategy, and multi-level nonprofit change during the Great Depression. VOLUNTAS: International Journal of Voluntary and Nonprofit Organizations. https://doi.org/10. 1007/s11266-017-9948-8.

Hsieh, H.-F., \& Shannon, S. (2005). Three approaches to qualitative content analysis. Qualitative Health Research, 15(9), $1277-1288$.

Hwang, H., \& Powell, W. (2009). The rationalization of charity: The influence of professionalism in the nonprofit sector. Administrative Science Quarterly, 54(2), 268-298.

Jakobson, L., \& Sanovich, S. (2010). The changing models of the Russian third sector: Import substitution phase. Journal of Civil Society, 6(3), 279-300.

Javeline, D., \& Lindemann-Komarova, S. (2010). A balanced assessment of Russian civil society. Journal of International Affairs, 63(2), 171-188.

Kings, L., \& Kravchenko, Z. (2018). Civilsamhällets rationalisering i Sverige och Ryssland. In P. Turunen, \& S. Sjöberg (Eds.), Samhällsarbete: aktörer, arenor och perspektiv. Lund: Studentlitteratur (pp. forthcoming).

Knapp, M., Robertson, E., \& Thomason, C. (1990). Public money, voluntary action: Whose welfare? In H. Anheier \& W. Seibel (Eds.), The Third Sector: Comparative Studies of Nonprofit Organization (pp. 183-218). Berlin: Walter de Gruyter.

Knutsen, W. L. (2012). Adapted institutional logics of contemporary nonprofit organizations. Administration \& Society, 44(8), 985-1013.

Krasnopolskaya, I. (2012). Korporativnoe volonterstvo v Rossii: osnovnye kharakteristiki. (Corporate volonteering in Russia: general characteristics). In T. Bachinskaya (Ed.), Korporativnoe volonterstvo v Rossii. Sbornik luchschikh praktik (pp. 36-41). Moskva: Tsentr razvitiya filantropii "Soprichastnost".

Krasnopolskaya, I., Skokova, Y., \& Pape, U. (2015). Governmentnonprofit relations in Russia's regions: An exploratory analysis. VOLUNTAS: International Journal of Voluntary and Nonprofit Organizations, 6(6), 2238-2266.

Kulmala, M. (2011). Russian state and civil society interaction: An ethnographic study. Laboratorium, 3(1), 51-83.

Kulmala, M., Rasell, M., \& Chernova, Z. (2017). Overhauling Russia's child welfare system: Institutional and ideational factors behind the paradigm shift. Zhurnal issledovanii sotsial'noi politiki, 15(3), 353-366.

Livshin, A., \& Weitz, R. (2006). Civil society and philanthropy under Putin. The International Journal of Not-for-Profit Law, 8(3), 6-11.

Ljubownikow, S., \& Crotty, J. (2017). Managing boundaries: The role of non-profit organisations in Russia's managed democracy. Sociology, 51(5), 940-956.

Lounsbury, M. (2007). A tale of two cities: Competing logics and practice variation in the professionalizing mutual funds. Academy of Management Journal, 50(2), 289-307.

Maier, F., Meyer, M., \& Steinbereithner, M. (2016). Nonprofit organizations becoming business-like: A systematic review. Nonprofit and Voluntary Sector Quarterly, 45(1), 64-88.

Marwell, N., \& Calabrese, T. (2015). A deficit model of collaborative governance: Government-nonprofit fiscal relations in the provision of child welfare services. Journal of Public Administration Research and Theory, 25(4), 1031-1058.

Mercer, C. (2002). NGOs, civil society and democratization: A critical review of the literature. Progress in Development Studies, 2(1), 5-22.

Meyer, J., Scott, W., \& Deal, T. (1983). Institutional and technical sources of organizational structure: Explaining the structure of educational organizations. In J. Meyer \& W. Scott (Eds.), Organizational Environments: Ritual and Rationality (pp. 45-67). Beverly Hills: Sage.

Meyer, M., \& Simsa, R. (2014). Developments in the third sector: The last decade and a cautious view into the future. In M. Freise \& T. Hallmann (Eds.), Modernizing Democracy (pp. 203-215). New York: Springer.

Ministry of Economic Development. (2017). Doklad o deiatel'nosti i razvitii sotsial'no-orientirovannykh nekommercheskikh organizatsii. (Report on development of socially-oriented nonprofit organizations). Online http://nko.economy.gov.ru/Files/NewsDo cuments/ef54d172-13a8-43a2-ae4b-a7fe7becade7.pdf. Accessed 08 September 2017.

Moskovskaya, A., Berendyaev, A., \& Moskvina, A. (2017). Between social and economic good: conflicting projects of legitimation of social entrepreneurship in Russia. Monitoring of Public Opinion: Economic and Social Changes, 6, 31-51.

Moskovskaya, A., \& Mamuta, M. (2008). Predposylki razvitiia sotsial'nogo predprinimatel'stva v Rossii-vozmozhnosti mikrofinansirovaniia. (Preconditions of development of social entrepreneurship in Russia: Opportunities for microfinancing). Moskva: NIU "Vysshaia Shkola Ekonomiki".

Moskovskaya, A., \& Soboleva, I. (2016). Social entrepreneurship in the system of social policy: International experience and prospects of Russia. Studies in Russian Economic Development, 27(6), 683-688.

Najam, A. (2000). The four-c's of third sector-government relations: Cooperation, confrontation, complementarity, and co-optation. Nonprofit Management and Leadership, 10(4), 375.

Nefedova, A. (2015). Social entrepreneurship in Russia: Key players and development potentiality, Higher School of Economics Research Paper No. WP BRP 51/STI/2015. Online, http://dx.doi. org/10.2139/ssrn.2696903. Accessed 16 October 2017. 
NPO Development Center. (2014). Gosudarstvennaia podderzhka NKO v Sankt Peterburge: soderzhatel'nye rezul'taty i sotsial'noekonomicheskie effekty. (State support to NPOs in St Petersburg: Substantial results and socioeconomic effects). St Petersburg: Tsentr razvitiia nekommercheskikh organizatsyi.

Nikolaeva, D. (2017). Sotsial'nykh predprinimatelei vvedut v zakon. (Social entrepreneurs will become legal). Kommersant, 21 January 2017, Online, http://kommersant.ru/doc/3188689. Accessed 01 May 2017.

OECD. (2017). Exchange rates, Total, National currency units/US dollar, 2000-2016. Online, https://data.oecd.org/conversion/ exchange-rates.htm. Accessed 12 October 2017.

Oliver, C. (1991). Strategic responses to institutional processes. The Academy of Management Review, 16(1), 145-179.

Ostrom, E. (1990). Governing the commons: The evolution of institutions for collective action. Cambridge: Cambridge University Press.

Pache, A.-C., \& Santos, F. (2013). Inside the hybrid organization: Selective coupling as a response to competing institutional logics. Academy of Management Journal, 56(4), 972-1001.

Pfeffer, J., \& Salanick, G. (1978). The external control of organizations. New York: Harper \& Row.

Richter, J. (2008). Governmentality, foreign aid and Russian NGOs. In P. Romanov \& E. Yarskaya-Smirnova (Eds.), Social Policy in Russia: Reforms and Everyday Life (pp. 349-367). Moskva: Variant, CSPGI.

Salamon, L. (1987). Of market failure, voluntary failure, and thirdparty government: Toward a theory of government-nonprofit relations in the modern welfare state. Journal of Voluntary Action Research, 16(1-2), 29-49.

Salamon, L., \& Anheier, H. (1998). Social origins of civil society. VOLUNTAS: International Journal of Voluntary and Nonprofit Organizations, 9(3), 213-248.

Salamon, L., Benevolenski, V., \& Jakobson, L. (2015). Penetrating the dual realities of government-nonprofit relations in Russia. VOLUNTAS: International Journal of Voluntary and Nonprofit Organizations, 26(6), 2178-2214.

Skelcher, C., \& Smith, S. R. (2015). Theorizing hybridity: Institutional logics, complex organizations, and actor identities: The case of nonprofits. Public Administration, 93(2), 433-448.
Stewart, S., \& Dollbaum, J. M. (2017). Civil society development in Russia and Ukraine: Diverging paths. Communist and PostCommunist Studies, 50(3), 207-220.

Stinchcombe, A. (2005). The logic of social research. Chicago: The University of Chicago Press.

Struyk, R. J. (2003). Contracting with NGO's for social services. Building civil society and efficient local government in Russia. Washington, DC: The Urban Institute. Online http://pdc.ceu.hu/ archive/00004574/. Accessed 04 April 2017.

Sundstrom, M. L. (2005). Foreign assistance, international norms, and NGO development: Lessons from the Russian campaign. International Organization, 59(2), 419-449.

Tarasenko, A. (2015). Russian welfare reform and social NGOs: Strategies for claim-making and service provision in the case of St Petersburg. East European Politics, 31(3), 294-313.

Tikhonovich, L. (2015). Popavshie v reestry-kak NKO sebia chuvstvuiut $\mathrm{v}$ roli postavschikov sotsial'nykh uslug. (In the registry-what happened to NPOs that supply social services). Moskva: Agenstvo sotsial'noi informatsii. Online, https://www. asi.org.ru/news/2015/08/28/popavshie-v-reestry-kak-nko-sebyachuvstvuyut-v-roli-postavshhikov-sotsialnyh-uslug/. Accessed 31 March, 2017.

Transparency International. (2014). Issledovanie informatsionnoi otkrytosti sistemy raspredeleniia gosudarstvennoi podderzhki NKO: 2011-2012. (Study of openess of information about distribution of public support to NPOs: 2011-2012). Moscow: Transparency International.

Tulaeva, S., Tysiachniouk, M., \& Henry, L. (2017). Strategies of environmental NGOs in the context of the law on foreign agents: Games with formality. Laboratorium, 9(3), 18-43.

World Bank. (2017). GDP (current US\$). Online, https://data. worldbank.org/indicator/NY.GDP.MKTP.CD. Accessed 12 October 2017.

Young, D., \& Salamon, L. (2002). Commercialization, social ventures, and for-profit competition. In L. M. Salamon (Ed.), The State of Nonprofit America (pp. 423-446). Washington, DC: Brookings Institution Press.

Zhang, D. D., \& Swanson, L. A. (2013). Social entrepreneurship in nonprofit organizations: An empirical investigation of the synergy between social and business objectives. Journal of Nonprofit and Public Sector Marketing, 25(1), 105-125. 